\title{
Immunomodulatory effects in workers exposed to naturally occurring asbestos fibers
}

\author{
CATERINA LEDDA ${ }^{1}$, CHIARA COSTA $^{2}$, SERENA MATERA ${ }^{1}$, BEATRICE PUGLISI ${ }^{1}$, VALENTINA COSTANZO ${ }^{1}$, \\ MASSIMO BRACCI ${ }^{3}$, CONCETTINA FENGA $^{2}$, VENERANDO RAPISARDA $^{1}$ and CARLA LORETO ${ }^{4}$ \\ ${ }^{1}$ Section of Occupational Medicine, Department of Clinical and Experimental Medicine, University of Catania, \\ Catania; ${ }^{2}$ Section of Occupational Medicine, Department of Biomedical, Odontoiatric, Morphological and \\ Functional Images, University of Messina, Messina; ${ }^{3}$ Section of Occupational Medicine, Department of Clinical \\ and Molecular Sciences, Polytechnic University of Marche, Ancona; ${ }^{4}$ Section of Human Anatomy and Histology, \\ Department of Biomedical and Biotechnology Sciences, University of Catania, Catania, Italy
}

Received December 30, 2016; Accepted February 21, 2017

DOI: $10.3892 / \mathrm{mmr} .2017 .6384$

\begin{abstract}
Natural asbestiform fibers are defined 'naturally occurring asbestos' (NOA) and refer to the mineral as a natural component of soils or rocks. The release of NOA fibers into the air from rocks or soils by routine human activities or natural weathering processes represents a risk for human beings. Fluoro-edenite (FE) is a NOA fiber detected in the benmoreitic lava in the area of Biancavilla, South-west slope of Mt. Etna. The aim of the present study was to investigate FE immunotoxicity pathways in a group of 38 occupationally exposed construction workers, in order to find any biological markers of its effect. Subjects underwent respiratory function tests and HRCT total chest scanning. Serum IL-1 $\beta$, IL-6, IL-8 and TNF- $\alpha$ were measured. The presence of PPs was significantly greater in subjects exposed than in the control (25 vs. 2). In subjects exposed to FE, IL-1 $\beta$ and TNF- $\alpha$ values were significantly higher than the controls. The previously observed increase of IL-1 $\beta$ and IL-18 showed a probable involvement of the proteic complex defined inflammosome by FE fibers.
\end{abstract}

\section{Introduction}

Occupational and/or environmental exposure to some types of asbestos fibers is related with both malignant and nonmalignant pulmonary diseases (1-3), of which malignant mesothelioma (MM) and lung cancer are the most typical ones (4). Instead, non-malignant asbestos-related diseases

Correspondence to: Dr Caterina Ledda, Section of Occupational Medicine, Department of Clinical and Experimental Medicine, University of Catania, Via Santa Sofia 78, I-95123 Catania, Italy E-mail: cledda@unict.it

Key words: cytokine, interleukin, fluoro-edenite, Biancavilla, fibers, malignant pleural mesothelioma, NLRP3, inflammasome include pleural plaques (PPs), pleural effusions, diffuse pleural thickening and parenchymal fibrosis (5-8).

Natural asbestiform fibers are defined 'naturally occurring asbestos' (NOA) (9-11). The word refers to fibers which are natural components of soils or rocks. The release of NOA fibers into the air by human work activities or natural weathering processes is a potential risk for the general population (9). These fibers have been detected in various parts worldwide, such as Greece, Turkey, Cyprus, Corsica, New Caledonia, Afghanistan, Russia, Montana (USA) and Italy (12-17).

In the $1990 \mathrm{~s}$, a greatly increased standardized rate of mortality from MM was observed after epidemiological studies in the municipality of Biancavilla (Sicily, Italy) $(17,18)$. Later studies spotted an asbestiform mineral fibre, called fluoro-edenite (FE), in the lava rocks excavated from a local stone quarry. The derived material had been used locally for about 50 years for building (17-19). The quarry was shut down in 1998 (20). Following some in vitro, in vivo and epidemiological studies (21-25) the IARC (Lyon, France) classified FE as carcinogenic to humans, but only for MM (26).

The relationship between exposure to asbestos and adverse health effects has been extensively studied (27). These asbestos-related diseases are well documented and approximately 107,000 mortalities are attributable to exposure to fiber worldwide, annually (28-30). Little has been established with regard to FE-related diseases (31-38); however, epidemiological studies have shown that these fibers may cause chronic obstructive lung disease (18,39), PPs and MMs (17,39).

These pathologies are the result of imbalanced inflammatory processes that is the early response to inhaled fibers. Historically, immune system cells have been regarded as the main players in initiating acute or chronic inflammation. However, recent studies have shown that epithelial cells of the respiratory tract and mesothelial cells lining the body cavities are capable of initiating inflammatory events after exposure to pathogenic fibers in the absence of cells of the immune system (40). The aim of this study was to detect FE immunotoxicity pathways in a group of occupationally exposed construction workers (CW), to find any biological markers of its effect. 


\section{Materials and methods}

Ethics statement. The research protocol received the approval of the Ethics Committee of Catania University Hospital (Catania, Italy) and the written informed consent of all subjects was acquired including them in the study.

Study population. Thirty-eight construction workers residing and working in the area of Biancavilla (Sicily, Italy) were invited to participate in this study. In the same period, 38 construction workers living and working least $40 \mathrm{~km}$ away the area of Biancavilla were recruited as control group. Exclusion criteria were thoracic diseases (e.g. asthma, bronchopneumonia, and tuberculosis), previous exposure to asbestos and involvement in construction work in the Biancavilla area for $<1$ year (the latter only for exposed subjects). A questionnaire was used to obtain information on medical and occupational history, use of medications, smoking and drinking habits. A free medical check, including spirometry and a high-resolution computer tomography (HRCT) chest scan, was given to all workers.

Clinical investigations. Respiratory function tests were carried out using a bell spirometer (Biomedin, Padova, Italy). Equipment, calibration and maneuvers were in conformity with the American Thoracic Society (ATS) guidelines. Forced vital capacity, forced expiratory volume in $1 \mathrm{sec}$, peak expiratory flow, maximal expiratory flow rate at $25-75 \%$ of the vital capacity, total lung capacity and TLCO were assessed and expressed as a proportion of the European Coal and Steel Community reference values, adjusted to individual characteristics (age, weight and height) checked at the time of testing.

Subjects underwent HRCT total chest scanning using an Optima CT 580W (GE Healthcare, Fairfield, CT, USA) without contrast medium. Interstitial and/or pleural abnormalities were recorded. Pleural plaques (PPs) are circumscribed quadrangular elevations with sharp borders and density comparable to tissue, with/without signs of calcification and expressed in terms of frequency and percentage. Parenchymal abnormalities (PA) (subpleural dependent opacity, subpleural curvilinear opacities, subpleaural perpendicular lines, parenchymal nodules, honeycombing and ground glass opacities) were expressed in terms of frequency and percentage.

Laboratory tests. Venous blood $(10 \mathrm{ml})$ was collected in the morning, following overnight fasting, to determine red blood cell count, haematocrit, haemoglobin levels, white blood cell count, erythrocyte sedimentation rate, C-reactive protein levels and liver enzyme (aspartate aminotransferase and alanine aminotransferase) levels. For cytokine detection, blood samples were drawn into vacuum tubes with gel and clot activator (Vacuette, Greiner Bio-One, Kremsmünster, Austria) before analysis. After collection, the tubes were left in an upright position for at least $30 \mathrm{~min}$ at room temperature but no more than $60 \mathrm{~min}$. Samples were then centrifuged at $3500 \mathrm{rpm}$ for $10 \mathrm{~min}$, then serum was separated and stored at $-20^{\circ} \mathrm{C}$ until analysis. Serum interleukin-1 $\beta$ (IL-1 $\beta$ ), IL-6, IL-8 and tumor necrosis factors- $\alpha$ (TNF- $\alpha$ ) were measured using highly sensitive quantitative sandwich assays (Quantikine ELISA kit, R\&D Systems, Minneapolis, MN, USA). The instruments were
Table I. Main features of samples and main results.

\begin{tabular}{lccc}
\hline Features & $\begin{array}{c}\text { Exposed } \\
\text { workers }\end{array}$ & $\begin{array}{c}\text { Non-exposed } \\
\text { workers }\end{array}$ & P-value \\
\hline Gender (male) & $38(100 \%)$ & $38(100 \%)$ & NS \\
Age (years) & $53.8 \pm 7.9$ & $54.4 \pm 6.5$ & NS \\
BMI (kg/m²) & $23.1 \pm 1.8$ & $22.7 \pm 1.7$ & NS \\
Smokers & $17(45 \%)$ & $19(50 \%)$ & NS \\
Alcohol & $16.4 \pm 3.5$ & $17.1 \pm 2.9$ & NS \\
consumption (g/day) & & & \\
Working age (years) & $21.2 \pm 9.3$ & $22.1 \pm 10.1$ & NS \\
Presence of PPs & $25(66 \%)$ & $2(5 \%)$ & $<0.0001$ \\
Presence of PAs & $3(8 \%)$ & $0(0 \%)$ & $<0.0001$ \\
IL-1 $\beta$ (pg/ml) & $27.51 \pm 8.43$ & $15.28 \pm 5.64$ & $<0.0001$ \\
IL-6 (pg/ml) & $13.07 \pm 3.25$ & $12.12 \pm 20.15$ & NS \\
IL-8 (pg/ml) & $18.43 \pm 9.27$ & $17.25 \pm 8.76$ & NS \\
TNF $\alpha(\mathrm{pg} / \mathrm{ml})$ & $21.14 \pm 6.13$ & $9.79 \pm 3.81$ & $<0.0001$ \\
\hline
\end{tabular}

BMI, body mass index; NS, not significant.

adjusted and internal quality control was performed using the same lot of the manufacturer's control and calibration material throughout the study.

Statistical analysis. Data were summarized as mean \pm SD for continuous variables and frequencies for categorical variables. Normality was checked by Kolmogrov-Smirnov test and homogeneity of variance by Levene's test. T-test was used for analyzed continuous variance, Fischer's test for categorical variables. Statistical analyses were performed by SPSS ver. 22 (IBM, Armonk, NY, USA) and GraphPad Prism ver. 6.0 (GraphPad Software, Inc., La Jolla, CA, USA).

\section{Results}

Application of the exclusion criteria did not cause any subject to be excluded from the sample. The main sample characteristics are reported in Table I. All 38 FE exposed CWs had been living in Biancavilla for $>35$ years, and $74 \%(n=28)$ were born there. Besides, all had been working almost exclusively in and around Biancavilla. As to their occupational history, 21 (55\%) of the participants revealed they had personally handled and worked with gravel excavated from Mount Calvario quarry until 1998. Furthermore, all had been involved in restoring houses dating back to the 1950s, when the lava from the quarry had been widely used as a building material.

Age, body mass index, smoking habits, alcohol consumption and working age did not differ between exposed and control. Blood examination tests were within the normal range in all subjects. Functional respiratory tests were within the normal range for all participants. A restrictive ventilatory defect was detected in two subjects (5\%) and an obstructive ventilatory defect observed in one (3\%) of the exposed group. Control subjects were all in the normal range. TLCO was less in two additional participants of exposed group (data not shown).

The HRCT findings are reported in Table I. HRCT scans revealed low-grade fibrosis in 3 workers (one unilateral and 


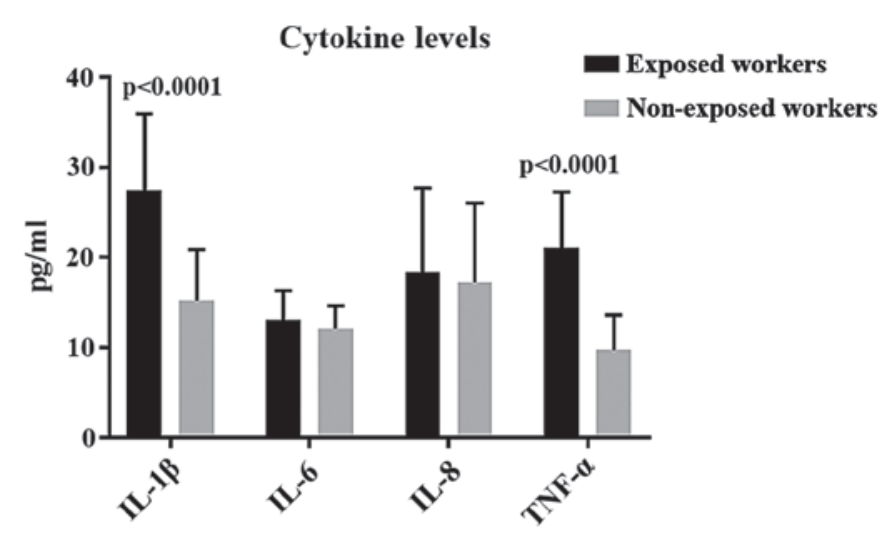

Figure 1. Mean levels of IL-1 $\beta$, IL-6, IL- 8 and TNF- $\alpha$ detected in fluoroedenite (FE) exposed construction workers (CW) and controls.

two bilateral). In the exposed group, pleural involvement was documented in $25(66 \%)$ subjects, of whom $21(84 \%)$ had bilateral plaques. Calcifications were detected in $5(17 \%)$ participants. In control subjects PPs were detected in $5 \%$ of cases $(n=2)$ (Table I).

Cytokine mean levels are reported in Fig. 1. In FE exposed subjects, TNF- $\alpha$ or IL- $1 \beta$ values were significantly higher $(\mathrm{P}<0.0001)$ than the controls, whereas IL-6 and IL-8 values were higher, although not significantly $(\mathrm{P}>0.05)$.

\section{Discussion}

A number of observations show that altered immune responses are also important in asbestos respiratory toxicity (41). Some of the major cytokines and growth factors involved in the pathogenesis of lung diseases include IL-1, TNF- $\alpha$, transforming growth factor- $\beta$ (TGF- $\beta$ ), platelet derived growth factor (PDGF) and IL-8. These agents augment cellular injury and trigger fibroblast proliferation and collagen deposition. Although alveolar macrophages (AM) are thought to be the primary source of these proteins, a previous molecular study suggests that pulmonary epithelial cells are also involved (42). Further evidence suggests that TNF- $\alpha$ is a key cytokine involved in asbestos induced lung toxicity $(43,44)$. TNF- $\alpha$ can increase the levels of alveolar type II cell Macrophage Inflammatory Proteins- $1 \alpha$ (MIP- $1 \alpha)$ mRNA, which suggests that TNF- $\alpha$ can promote pulmonary inflammation through its effects on epithelial cells (45).

In our study, significantly higher levels of TNF- $\alpha$ were detected in FE-exposed subjects, compared to the control ones. Simeonova and colleagues $(46,47)$ found out that asbestos and $\mathrm{H}_{2} \mathrm{O}_{2}$ both activate NF- $\kappa$ B and NF-IL-6 in A549 and normal human bronchial epithelial cells which, in turn, stimulate IL-6 and IL-8 gene expression and protein release. A function for reactive oxygen species (ROS) was clarified by their observation that $\mathrm{HO}^{*}$ scavengers and $\mathrm{N}$-acetylcysteine (NAC) each decreased asbestos or $\mathrm{H}_{2} \mathrm{O}_{2}$ induced NF- $\kappa \mathrm{B}$ and NF-IL-6 activity as well as IL-8 and IL-6 protein expression. In vitro studies conducted by Travaglione et al $(48,49)$, demonstrated that FE interfered with epithelial cell physiology, by reducing the proliferation rate without perturbing the cell cycle and increasing the release of pro-inflammatory cytokines IL-6 and IL-8, from pulmonary epithelial cells.
In our study, FE-exposed subjects showed increased levels of IL-6 and IL-8, although in a non-statistically relevant way. Higher levels of IL-6, IL- 8 and TNF- $\alpha$, have been observed more recurrently overexpressed in the microenvironment of mesothelial cells during neoplastic transformation (50-52). The continuous stimulation of mesothelial cells from FE fibers could account for the increased values of these cytokines, particularly the increase of TNF- $\alpha$, that is involved in the resistance against fiber toxicity (53). As a matter of fact, significantly greater quantities of PPs were observable in exposed subjects than in the control groups $25(66 \%)$ vs. $2(5 \%)$. PPs can arise even after relatively low exposure to asbestiform fibers and are the most common non-malignant effects (31-33,35,54-57).

Most research on the role of inflammation in asbestosrelated diseases has been centred on immune cellular response, including the first cell type accumulating at sites of initial deposition of inhaled asbestos fibres (42). When the injury occurs, mesothelial cells can recruit neutrophils, monocytes and lymphocytes by generating chemokines and cytokines which cause mesothelial cells to release growth factors with paracrine functions (50-52,58-60). New evidence on human mesothelial cells sustains a model where an autocrine loop is perpetrated by fibre-induced inflammasone NLRP3 (NLR family pyrin domain containing 3) priming and activation, with the subsequent augmented pro-inflammatory growth factors transcription activity (61-64).

The inflammasome is a multiprotein complex that links proIL-1 $\beta$ to its upstream activator. This complex is composed of Pycard, NALP1, caspase-1 and likely caspase-5. It is expressed in myeloid cells and is a component of the immune system (65). The IL-1 super-family of cytokines encompasses at least 11 members, which include IL-1 $\alpha$, IL-1 $\beta$, and IL-18 (66). The inflammasome is responsible for the activation of inflammatory processes (65) and has been shown to induce caspase-1 dependent pyroptosis which is a form of cell death characterized by both apoptosis and necrosis (67).

A recent study (40) showed that exposure to asbestos and asbestiform fibers (i.e. erionite) may trigger and activate the inflammasome via multiple mechanisms (40). These fibers cause dose-related damage to the cell membrane at high concentrations, are phagocytized and can break phagolysosomes. These processes may lead to the activation of ROS via many paths. Inflammasome-related caspase-1 activation leads directly to the maturation and secretion of IL-1 $\beta$ and IL-18, as well as other inflammatory mediators such as IL-1 $\alpha$ and high mobility group box-1 (HMGB1). These chemokines and cytokines either directly or indirectly lead to acute and chronic inflammation, the latter resulting in various particle and fiberassociated pulmonary and pleural pathologies (40).

Procaspase- 1 is recruited to the inflammasome complex and processed to active caspase-1, which processes IL-1 and IL-18 into their active forms $(65,68)$. This can account for the high serum levels of IL-1 $\beta$ detected in FE-exposed workers compared to control ones. Besides, in a previous study carried out on CWs in Biancavilla, high levels of IL-18 were observed which well correlated with the presence of PPs and lung parenchimal fibrosis (31). IL-1 $\beta$ helps T-cell survival, B-cell proliferation and antibody production, as well as mediating leukocyte transmigration $(69,70)$. IL- $1 \beta$ roles 
in carcinogenicity entails recruitment of myeloid-derived suppressor cells (MDSCs) that prevent natural killer (NK) cells from developing and functioning (71). IL-18 can work synergistically with IL-12 to induce interferon- $\gamma$ (IFN $\gamma$ ) production by activating T- and NK-cells $(69-70,72)$.

The pro-inflammatory cytokine IL- $1 \beta$, which can be inflammasome-dependent, is a critical mediator of inflammation-promoting carcinogenesis (73-76) and fibrosis (77,78). Cell death mechanisms such as apoptosis and necrosis and release of chemokines/cytokines and alarmines such as HMGB1 and TNF- $\alpha$, may help cancer regress, resist toxicity by fibers and cell growth $(62,79)$, in inflammasome-dependent and -independent pathways (80). The transcription factors, activator protein-1 (AP-1) and NF- $\kappa \mathrm{B}$ that may change inflammation-induced tumor growth into cancer regression (79), are also signals inducing the transcription or priming of pro-IL-1 $\beta$.

The induction of caspase-1 dependent pyroptosis, a type of cell death characterized by both apoptotic and necrotic features, is another important function of inflammasomes (81). This progression features nuclear DNA fragmentation, plasma membrane rupture and release of inflammatory mediators such as IL-1 $\alpha$, IL-1 $\beta$, IL-33 and HMGB1 which play significant roles in inflammatory processes $(72,81)$. Consequently, the inflammasome and inflammation can promote proliferation and maturation of target cells and immune suppression in tumors (82). It is assembled in response to a wide range of conserved exogenous molecules including asbestos (83). Multifaceted inflammasomes are critical in sensing and responding to a variety of extracellular and intracellular stresses through several pathways and may be important in both pulmonary defense and promulgation of chronic inflammation leading to pathologies (40).

In the lungs, highly inflammatory cytokines of the IL-1 family, including IL-1 $\beta$, are key factors to inflammation. For instance, IL-6, a pleiotropic inflammatory cytokine frequently released in tandem with IL-1 $\beta$, is a key growth-promoting and anti-apoptotic factor that is also involved in immune regulation and inflammation $(84,85)$. IL-6 is frequently expressed in malignant respiratory epithelial cells, and high circulating levels in serum are related to a poor prognosis in lung cancer patients $(86,87)$. Its potential use as a biomarker and prognostic indicator is bolstered by the fact that it is not detected in the serum of healthy individuals and patients with benign lung pathologies (40). Comar et al (88) observed significant high levels of IL-6 in MM patients. This is in line with what we observed with regard to the increased level of IL-6 in the exposed group compared to the controls, although not significantly; this may derive from mesothelial involvement, although without cancer lesions.

Asbestiform fibers can trigger and activate the NLRP3 inflammasome in mesothelial and epithelial cells, as well as in cells of the immune system via multiple pathways. Inflammasome priming and activation may play vital roles in both early lung and pleural injury as well as in inflammation, tumor initiation and promotion. TNF- $\alpha$, a protein implicated in both proliferation of mesothelial cells and prevention of asbestos-induced injury $(89,90)$, it may also stimulate MM cell survival through the induction of genes encoding NF- $\mathrm{B}$-dependent anti-apoptotic molecules $(91,92)$ and activate chemo-resistance. TNF- $\alpha$ receptors are regulated by both TNF- $\alpha$ and IL-1 $\alpha$ in human mesothelial cells (58) that synthesize and release both IL-1 $\beta$ (93) and IL-1 $\alpha$ after injury $(67,68)$. The fact that the chemotactic and autocrine growth factor IL-8 (94-97) is generated by human mesothelial cells in response to TNF- $\alpha$ and IL-1 released by macrophages or after exposure to asbestos (98), supports the concept that inflammasome-mediated mature $1 \mathrm{~L}-1 \beta$ release is essential to the production of other cytokines and chemokines critical to the development of MMs (40).

In our study, the observation of significantly high levels of TNF- $\alpha$ in exposed subjects could be accounted for with the resistance action against the stimulus deriving from inhaling FE fibers. As described for asbestos, it is conceivable that FE may promote the NLRP3 inflammasome in macrophages, monocytes and lung epithelial cells, leading to IL-1 $\beta$ secretion $(91,92)$. Increased production of TGF- $\beta$, a hallmark of inflammation and the fibrotic process, triggers the activation, proliferation and trans-differentiation of epithelial cells and resident fibroblasts into collagen-producing myofibroblasts. This has been put down to inflammasome-induced secretion of mature IL-1 $\beta$ (98). IL-1 $\beta$ also triggers the secretion of neutrophil-attracting CXC chemokines, resulting in a further influx of neutrophils that amplify cell damage and oxidant release (99). Unlike macrophages and monocytes, NADPH oxidase-derived ROS are neither required for inflammasome priming nor activation by human neutrophils, but are necessary for exporting mature IL-1 $\beta$ from the cell (100). IL-1 $\beta$ secretion by AMs is enhanced by fibrogenic agents that also raise production of PDGF, a growth-promoting cytokine and chemo-tactic factor (101).

A recent immunohistochemical study, conducted in lung tissue of sheep exposed to FE fibers showed a significant activation of AM and mast cells (102). An in vitro study on mesothelial Met-5A and monocyte-macrophage J774 cells exposed to FE caused induction of the heat shock protein 70 (Hsp70), stimulated formation of ROS and NO (measured as nitrite). Exposure of cells to FE induced lactate dehydrogenase activity and decreased cell viability (103). It is conceivable that FE may trigger inflammatory processes that, like in the case of asbestos, may lead to the activation of inflammosome.

In this study, as well as in a previous one (31) on IL-18, where high IL-1 $\beta$ serum levels have been detected, both cytokines are primarily involved in the inflammosome activation process. Our results suggest that it is necessary to go on with research on immune-modulators involved in the pathogenic mechanisms responsible for FE related diseases.

\section{References}

1. Alberg AJ and Samet JM: Epidemiology of lung cancer. Chest 123 (Suppl): 21S-49S, 2003.

2. LaDou J: The asbestos cancer epidemic. Environ Health Perspect 112: 285-290, 2004.

3. Fujimoto N, Gemba K, Aoe K, Kato K, Yokoyama T, Usami I, Onishi K, Mizuhashi K, Yusa T and Kishimoto T: Clinical investigation of benign asbestos pleural effusion. Pulm Med 2015: 416179,2015

4. Prazakova S, Thomas PS, Sandrini A and Yates DH: Asbestos and the lung in the 21st century: An update. Clin Respir J 8: 1-10, 2014.

5. Hillerdal G: Non-malignant asbestos pleural disease. Thorax 36: 669-675, 1981. 
6. Guidotti TL, Miller A, Christiani D, Wagner G, Balmes J, Harber P, Brodkin CA, Rom W, Hillerdal G, Harbut M, et al; American Thoracic Society: Diagnosis and initial management of nonmalignant diseases related to asbestos. Am J Respir Crit Care Med 170: 691-715, 2004.

7. Cugell DW and Kamp DW: Asbestos and the pleura: A review. Chest 125: 1103-1117, 2004.

8. Gevenois PA, de Maertelaer V, Madani A, Winant C, Sergent G and De Vuyst P: Asbestosis, pleural plaques and diffuse pleural thickening: Three distinct benign responses to asbestos exposure. Eur Respir J 11: 1021-1027, 1998.

9. Bayram M, Dongel I, Bakan ND, Yalçin H, Cevit R, Dumortier P and Nemery B: High risk of malignant mesothelioma and pleural plaques in subjects born close to ophiolites. Chest 143: 164-171, 2013.

10. Kanarek MS: Mesothelioma from chrysotile asbestos: Update. Ann Epidemiol 21: 688-697, 2011.

11. Hansen J, de Klerk NH, Eccles JL, Musk AW and Hobbs MS Malignant mesothelioma after environmental exposure to blue asbestos. Int J Cancer 54: 578-581, 1993.

12. Constantopoulos SH: Environmental mesothelioma associated with tremolite asbestos: Lessons from the experiences of Turkey, Greece, Corsica, New Caledonia and Cyprus. Regul Toxicol Pharmacol 52 (Suppl 1): S110-S115, 2008.

13. Voisin C, Marin I, Brochard P and Pairon JC: Environmental airborne tremolite asbestos pollution and pleural plaques in Afghanistan. Chest 106: 974-976, 1994.

14. Schüz J, Schonfeld SJ, Kromhout H, Straif K, Kashanskiy SV, Kovalevskiy EV, Bukhtiyarov IV and McCormack V: A retrospective cohort study of cancer mortality in employees of a Russian chrysotile asbestos mine and mills: Study rationale and key features. Cancer Epidemiol 37: 440-445, 2013.

15. Sullivan PA: Vermiculite, respiratory disease, and asbestos exposure in Libby, Montana: Update of a cohort mortality study. Environ Health Perspect 115: 579-585, 2007.

16. Szychlinska MA, Parenti R, Loreto C, Salvatorelli L, Spadola S, Trovato FM, Pirri C, Rapisarda V, Pace MM, Magro G, et al: Fluoro edenite-associated pathogenesis in pleural malignant mesothelioma. Acta Med Mediter 30: 981-989, 2014.

17. Paoletti L, Batisti D, Bruno C, Di Paola M, Gianfagna A, Mastrantonio M, Nesti M and Comba P: Unusually high incidence of malignant pleural mesothelioma in a town of eastern Sicily: An epidemiological and environmental study. Arch Environ Health 55: 392-398, 2000

18. Di Paola M, Mastrantonio M and Carboni M: Mortality from malignant pleural neoplasms in Italy in the years 1988-1992. ISTISAN 96, Rome, pp1-30, 1996.

19. Comba P, Gianfagna A and Paoletti L: Pleural mesothelioma cases in Biancavilla are related to a new fluoro-edenite fibrous amphibole. Arch Environ Health 58: 229-232, 2003.

20. Miozzi E, Rapisarda V, Marconi A, Costa C, Polito I, Spandidos DA, Libra M and Fenga C: Fluoro-edenite and carbon nanotubes: The health impact of 'asbestos-like' fibres. Exp Ther Med 11: 21-27, 2016

21. Ballan G, Del Brocco A, Loizzo S, Fabbri A, Maroccia Z, Fiorentini $\mathrm{C}$ and Travaglione S: Mode of action of fibrous amphiboles: The case of Biancavilla (Sicily, Italy). Ann Ist Super Sanita 50: 133-138, 2014

22. DeNardo P, Bruni B, Paoletti L, Pasetto R and Sirianni B Pulmonary fibre burden in sheep living in the Biancavilla area (Sicily): Preliminary results. Sci Total Environ 325: 51-58, 2004.

23. Loreto C, Rapisarda V, Carnazza ML, Musumeci G, Valentino M, Fenga $\mathrm{C}$ and Martinez G: Fluoro-edenite fibres induce lung cell apoptosis: An in vivo study. Histol Histopathol 23: 319-326, 2008.

24. Martinez G, Loreto C, Rapisarda V, Masumeci G, Valentino M and Carnazza ML: Effects of exposure to fluoro-edenite fibre pollution on the respiratory system: An in vivo model. Histol Histopathol 21: 595-601, 2006.

25. Soffritti M, Minardi F, Bua L, Degli Esposti D and Belpoggi F: First experimental evidence of peritoneal and pleural mesotheliomas induced by fluoro-edenite fibres present in etnean volcanic material from Biancavilla (Sicily, Italy). Eur J Oncol 9: $169-175,2004$

26. Grosse Y, Loomis D, Guyton KZ, Lauby-Secretan B, El Ghissassi F, Bouvard V, Benbrahim-Tallaa L, Guha N, Scoccianti C, Mattock H, et al; International Agency for Research on Cancer Monograph Working Group: Carcinogenicity of fluoro-edenite, silicon carbide fibres and whiskers, and carbon nanotubes. Lancet Oncol 15: 1427-1428, 2014.
27. Bernstein D, Dunnigan J, Hesterberg T, Brown R, Velasco JAL, Barrera R, Hoskins J and Gibbs A: Health risk of chrysotile revisited. Crit Rev Toxicol 43: 154-183, 2013.

28. Robinson BWS and Lake RA: Advances in malignant mesothelioma. N Engl J Med 353: 1591-1603, 2005.

29. World Health Organization (WHO): Asbestos: elimination of asbestos-related diseases. http://www.who.int/mediacentre/factsheets/fs343/en/. Accessed January 21, 2017.

30. Ledda C and Rapisarda V: Malignant pleural mesothelioma: The need to move from research to clinical practice. Arch Med Res 47: 407, 2016.

31. Ledda C, Loreto C, Matera S, Massimino N, Cannizzaro E, Musumeci A, Migliore M, Fenga C, Pomara C and Rapisarda V: Early effects of fluoro-edenite: Correlation between IL-18 serum levels and pleural and parenchymal abnormalities. Future Oncol 12: 59-62, 2016

32. Ledda C, Loreto C, Bracci M, Mangano D, Migliore M, Ricceri V, Musumeci A, Costa C, Pomara C and Rapisarda V: High risk of pleural plaques and parenchymal abnormalities in women living in Biancavilla (Italy). Future Oncol 12: 63-65, 2016.

33. Ledda C, Pomara C, Bracci M, Mangano D, Ricceri V, Musumeci A, Ferrante M, Musumeci G, Loreto C, Fenga C, et al: Natural carcinogenic fiber and pleural plaques assessment in a general population: A cross-sectional study. Environ Res 150: 23-29, 2016.

34. Ledda C, Loreto C, Pomara C, Rapisarda G, Fiore M, Ferrante M, Bracci M, Santarelli L, Fenga C and Rapisarda V: Sheep lymphnodes as a biological indicator of environmental exposure to fluoro-edenite. Environ Res 147: 97-101, 2016.

35. Rapisarda V, Ledda C, Migliore M, Salemi R, Musumeci A, Bracci M, Marconi A, Loreto C and Libra M: FBLN-3 as a biomarker of pleural plaques in workers occupationally exposed to carcinogenic fibers: A pilot study. Future Oncol 11 (Suppl): $35-37,2015$

36. Fazzo L, Minelli G, De Santis M, Bruno C, Zona A, Marinaccio A, Conti S, Pirastu R and Comba P: Mesothelioma mortality surveillance and asbestos exposure tracking in Italy. Ann Ist Super Sanita 48: 300-310, 2012.

37. Loreto C, Carnazza ML, Cardile V, Libra M, Lombardo L, Malaponte G, Martinez G, Musumeci G, Papa V and Cocco L: Mineral fiber-mediated activation of phosphoinositide-specific phospholipase $\mathrm{c}$ in human bronchoalveolar carcinoma-derived alveolar epithelial A549 cells. Int J Oncol 34: 371-376, 2009.

38. Musumeci G, Loreto C, Cardile V, Carnazza ML and Martinez G: Immunohistochemical expression of retinoblastoma and phospho-retinoblastoma protein in sheep lung exposed to fluoro-edenite fibers. Anat Sci Int 85: 74-78, 2010.

39. Biggeri A, Pasetto R, Belli S, Bruno C, Di Maria G, Mastrantonio M, Trinca S, Uccelli R and Comba P: Mortality from chronic obstructive pulmonary disease and pleural mesothelioma in an area contaminated by natural fiber (fluoroedenite). Scand J Work Environ Health 30: 249-252, 2004.

40. Sayan M and Mossman BT: The NLRP3 inflammasome in pathogenic particle and fibre-associated lung inflammation and diseases. Part Fibre Toxicol 13: 51, 2016.

41. Churg A, Sun J and Zay K: Cigarette smoke increases amosite asbestos fiber binding to the surface of tracheal epithelial cells. Am J Physiol 275: L502-508, 1998.

42. Kamp DW and Weitzman SA: The molecular basis of asbestos induced lung injury. Thorax 54: 638-652, 1999.

43. Irani K, Xia Y, Zweier JL, Sollott SJ, Der CJ, Fearon ER, Sundaresan M, Finkel T and Goldschmidt-Clermont PJ: Mitogenic signaling mediated by oxidants in Ras-transformed fibroblasts. Science 275: 1649-1652, 1997.

44. Manna SK, Zhang HJ, Yan T, Oberley LW and Aggarwal BB: Overexpression of manganese superoxide dismutase suppresses tumor necrosis factor-induced apoptosis and activation of nuclear transcription factor-kappaB and activated protein-1. J Biol Chem 273: 13245-13254, 1998.

45. Byrnes RW: Evidence for involvement of multiple iron species in DNA single-strand scission by H2O2 in HL-60 cells. Free Radic Biol Med 20: 399-406, 1996.

46. Simeonova PP and Luster MI: Iron and reactive oxygen species in the asbestos-induced tumor necrosis factor-alpha response from alveolar macrophages. Am J Respir Cell Mol Biol 12: 676-683, 1995

47. Simeonova PP, Toriumi W, Kommineni C, Erkan M, Munson AE, Rom WN and Luster MI: Molecular regulation of IL-6 activation by asbestos in lung epithelial cells: Role of reactive oxygen species. J Immunol 159: 3921-3928, 1997. 
48. Travaglione S, Bruni BM, Falzano L, Filippini P, Fabbri A, Paoletti L and Fiorentini C: Multinucleation and pro-inflammatory cytokine release promoted by fibrous fluoro-edenite in lung epithelial A549 cells. Toxicol In Vitro 20: 841-850, 2006.

49. Travaglione S, Bruni B, Falzano L, Paoletti L and Fiorentini C: Effects of the new-identified amphibole fluoro-edenite in lung epithelial cells. Toxicol In Vitro 17: 547-552, 2003.

50. Adachi Y, Aoki C, Yoshio-Hoshino N, Takayama K, Curiel DT and Nishimoto N: Interleukin-6 induces both cell growth and VEGF production in malignant mesotheliomas. Int J Cancer 119: $1303-1311,2006$.

51. Galffy G, Mohammed KA, Nasreen N, Ward MJ and Antony VB Inhibition of interleukin-8 reduces human malignant pleural mesothelioma propagation in nude mouse model. Oncol Res 11 187-194, 1999.

52. Galffy G, Mohammed KA, Dowling PA, Nasreen N, Ward MJ and Antony VB: Interleukin 8: An autocrine growth factor for malignant mesothelioma. Cancer Res 59: 367-371, 1999.

53. Luo JL, Maeda S, Hsu LC, Yagita H and Karin M: Inhibition of NF-kappaB in cancer cells converts inflammation-induced tumor growth mediated by TNFalpha to TRAIL-mediated tumor regression. Cancer Cell 6: 297-305, 2004.

54. Clin B, Paris C, Ameille J, Brochard P, Conso F, Gislard A, Laurent F, Letourneux M, Luc A, Schorle E, et al: Do asbestosrelated pleural plaques on HRCT scans cause restrictive impairment in the absence of pulmonary fibrosis? Thorax 66 : 985-991, 2011.

55. Laurent F, Paris C, Ferretti GR, Beigelman C, Montaudon M, Latrabe V, Jankowski A, Badachi Y, Clin B, Gislard A, et al: Inter-reader agreement in HRCT detection of pleural plaques and asbestosis in participants with previous occupational exposure to asbestos. Occup Environ Med 71: 865-870, 2014.

56. Rapisarda V, Ledda C, Ricceri V, Arena F, Musumeci A, Marconi A, Fago L, Bracci M, Santarelli L and Ferrante M: Detection of pleural plaques in workers exposed to inhalation of natural fluoro-edenite fibres. Oncol Lett 9: 2046-2052, 2015.

57. Maxim LD, Niebo R and Utell MJ: Are pleural plaques an appropriate endpoint for risk analyses? Inhal Toxicol 27: 321-334, 2015.

58. Wang Y, Faux SP, Hallden G, Kirn DH, Houghton CE, Lemoine NR and Patrick G: Interleukin- $1 \beta$ and tumour necrosis factor- $\alpha$ promote the transformation of human immortalised mesothelial cells by erionite. Int J Oncol 25: 173-178, 2004.

59. Zanella CL, Posada J, Tritton TR and Mossman BT: Asbestos causes stimulation of the extracellular signal-regulated kinase 1 mitogen-activated protein kinase cascade after phosphorylation of the epidermal growth factor receptor. Cancer Res 56: $5334-5338,1996$.

60. Mantovani A, Allavena P, Sozzani S, Vecchi A, Locati M and Sica A: Chemokines in the recruitment and shaping of the leukocyte infiltrate of tumors. Semin Cancer Biol 14: 155-160, 2004

61. Eisenbarth SC and Flavell RA: Innate instruction of adaptive immunity revisited: The inflammasome. EMBO Mol Med 1: 92-98, 2009.

62. Dostert C, Pétrilli V, Van Bruggen R, Steele C, Mossman BT and Tschopp J: Innate immune activation through Nalp3 inflammasome sensing of asbestos and silica. Science 320: 674-677, 2008.

63. Hillegass JM, Miller JM, MacPherson MB, Westbom CM, Sayan M, Thompson JK, Macura SL, Perkins TN, Beuschel SL, Alexeeva V, et al: Asbestos and erionite prime and activate the NLRP3 inflammasome that stimulates autocrine cytokine release in human mesothelial cells. Part Fibre Toxicol 10: 39, 2013.

64. Fox SA, Loh SS, Mahendran SK and Garlepp MJ: Regulated chemokine gene expression in mouse mesothelioma and mesothelial cells: TNF- $\alpha$ upregulates both $\mathrm{CC}$ and $\mathrm{CXC}$ chemokine genes. Oncol Rep 28: 707-713, 2012.

65. Martinon F, Burns K and Tschopp J: The inflammasome: A molecular platform triggering activation of inflammatory caspases and processing of proIL- $\beta$. Mol Cell 10: 417-426, 2002.

66. Dinarello CA: Immunological and inflammatory functions of the interleukin-1 family. Annu Rev Immunol 27: 519-550, 2009.

67. Fink SL and Cookson BT: Apoptosis, pyroptosis, and necrosis: Mechanistic description of dead and dying eukaryotic cells. Infect Immun 73: 1907-1916, 2005.

68. Agostini L, Martinon F, Burns K, McDermott MF, Hawkins PN and Tschopp J: NALP3 forms an IL-1 $\beta$-processing inflammasome with increased activity in Muckle-Wells autoinflammatory disorder. Immunity 20: 319-325, 2004.

69. Dinarello CA: Interleukin-1 in the pathogenesis and treatment of inflammatory diseases. Blood 117: 3720-3732, 2011.
70. Sims JE and Smith DE: The IL-1 family: Regulators of immunity. Nat Rev Immunol 10: 89-102, 2010.

71. Colotta F, Re F, Muzio M, Bertini R, Polentarutti N, Sironi M, Giri JG, Dower SK, Sims JE and Mantovani A: Interleukin-1 type II receptor: A decoy target for IL-1 that is regulated by IL-4. Science 261: 472-475, 1993

72. Kim SH, Eisenstein M, Reznikov L, Fantuzzi G, Novick D, Rubinstein $\mathrm{M}$ and Dinarello CA: Structural requirements of six naturally occurring isoforms of the IL-18 binding protein to inhibit IL-18. Proc Natl Acad Sci USA 97: 1190-1195, 2000.

73. Tschopp J, Martinon F and Burns K: NALPs: A novel protein family involved in inflammation. Nat Rev Mol Cell Biol 4: 95-104, 2003

74. Bank U and Ansorge S: More than destructive: Neutrophil-derived serine proteases in cytokine bioactivity control. J Leukoc Biol 69: 197-206, 2001.

75. Martinon F, Agostini L, Meylan E and Tschopp J: Identification of bacterial muramyl dipeptide as activator of the NALP3/cryopyrin inflammasome. Curr Biol 14: 1929-1934, 2004.

76. Kanneganti TD, Ozören N, Body-Malapel M, Amer A, Park JH, Franchi L, Whitfield J, Barchet W, Colonna M, Vandenabeele P, et al: Bacterial RNA and small antiviral compounds activate caspase-1 through cryopyrin/Nalp3. Nature 440: 233-236, 2006.

77. Mariathasan S, Weiss DS, Newton K, McBride J, O'Rourke K, Roose-Girma M, Lee WP, Weinrauch Y, Monack DM and Dixit VM: Cryopyrin activates the inflammasome in response to toxins and ATP. Nature 440: 228-232, 2006.

78. Eisenbarth SC, Colegio OR, O'Connor W Jr, Sutterwala FS and Flavell RA: Crucial role for the Nalp3 inflammasome in the immunostimulatory properties of aluminium adjuvants. Nature 453: 1122-1126, 2008.

79. Krakowski $\mathrm{M}$ and Owens $\mathrm{T}$ : Interferon- $\gamma$ confers resistance to experimental allergic encephalomyelitis. Eur J Immunol 26: 1641-1646, 1996

80. Vermeire K, Heremans H, Vandeputte M, Huang S, Billiau A and Matthys P: Accelerated collagen-induced arthritis in IFN- $\gamma$ receptor-deficient mice. J Immunol 158: 5507-5513, 1997.

81. Chang JT, Segal BM, Nakanishi K, Okamura H and Shevach EM: The costimulatory effect of IL-18 on the induction of antigenspecific IFN- $\gamma$ production by resting T cells is IL-12 dependent and is mediated by up-regulation of the IL-12 receptor $\beta 2$ subunit. Eur J Immunol 30: 1113-1119, 2000.

82. Cua DJ, Sherlock J, Chen Y, Murphy CA, Joyce B, Seymour B, Lucian L, To W, Kwan S, Churakova T, et al: Interleukin-23 rather than interleukin-12 is the critical cytokine for autoimmune inflammation of the brain. Nature 421: 744-748, 2003.

83. Mills KHG, Dungan LS, Jones SA and Harris J: The role of inflammasome-derived IL-1 in driving IL-17 responses. J Leukoc Biol 93: 489-497, 2013.

84. Bettelli E, Carrier Y, Gao W, Korn T, Strom TB, Oukka M, Weiner HL and Kuchroo VK: Reciprocal developmental pathways for the generation of pathogenic effector TH17 and regulatory T cells. Nature 441: 235-238, 2006.

85. Mangan PR, Harrington LE, O'Quinn DB, Helms WS, Bullard DC, Elson CO, Hatton RD, Wahl SM, Schoeb TR and Weaver CT: Transforming growth factor- $\beta$ induces development of the $\mathrm{T}(\mathrm{H}) 17$ lineage. Nature 441: 231-234, 2006.

86. Veldhoen M, Hocking RJ, Atkins CJ, Locksley RM and Stockinger B: TGFbeta in the context of an inflammatory cytokine milieu supports de novo differentiation of IL-17-producing T cells. Immunity 24: 179-189, 2006.

87. Zielinski CE, Mele F, Aschenbrenner D, Jarrossay D, Ronchi F, Gattorno M, Monticelli S, Lanzavecchia A and Sallusto F: Pathogen-induced human TH17 cells produce IFN- $\gamma$ or IL-10 and are regulated by IL-1 $\beta$. Nature 484: 514-518, 2012.

88. Comar M,Zanotta N, Bonotti A, Tognon M, Negro C, Cristaudo A and Bovenzi M: Increased levels of C-C chemokine RANTES in asbestos exposed workers and in malignant mesothelioma patients from an hyperendemic area. PLoS One 9: e104848, 2014.

89. Davis GS, Pfeiffer LM and Hemenway DR: Persistent overexpression of interleukin-1 $\beta$ and tumor necrosis factor- $\alpha$ in murine silicosis. J Environ Pathol Toxicol Oncol 17: 99-114, 1998.

90. Pan LH, Ohtani H, Yamauchi K and Nagura H: Co-expression of TNF $\alpha$ and IL-1 $\beta$ in human acute pulmonary fibrotic diseases: An immunohistochemical analysis. Pathol Int 46: 91-99, 1996.

91. Beamer CA and Holian A: Scavenger receptor class A type I/II (CD204) null mice fail to develop fibrosis following silica exposure. Am J Physiol Lung Cell Mol Physiol 289: L186-L195, 2005. 
92. Holley JA, Janssen YMW, Mossman BT and Taatjes DJ: Increased manganese superoxide dismutase protein in type II epithelial cells of rat lungs after inhalation of crocidolite asbestos or cristobalite silica. Am J Pathol 141: 475-485, 1992.

93.Porter DW, Hubbs AF, Chen BT, McKinney W, Mercer RR, Wolfarth MG, Battelli L, Wu N, Sriram K, Leonard S, et al: Acute pulmonary dose-responses to inhaled multi-walled carbon nanotubes. Nanotoxicology 7: 1179-1194, 2013.

94.Liu RM: Oxidative stress, plasminogen activator inhibitor 1, and lung fibrosis. Antioxid Redox Signal 10: 303-319, 2008.

95. Carbone $\mathrm{M}$ and Yang H: Molecular pathways: Targeting mechanisms of asbestos and erionite carcinogenesis in mesothelioma. Clin Cancer Res 18: 598-604, 2012.

96. Donaldson K, Poland CA, Murphy FA, MacFarlane M, Chernova $\mathrm{T}$ and Schinwald A: Pulmonary toxicity of carbon nanotubes and asbestos - similarities and differences. Adv Drug Deliv Rev 65: 2078-2086, 2013.

97. Goldberg JL, Zanella CL, Janssen YMW, Timblin CR, Jimenez LA, Vacek P, Taatjes DJ and Mossman BT: Novel cell imaging techniques show induction of apoptosis and proliferation in mesothelial cells by asbestos. Am J Respir Cell Mol Biol 17: 265-271, 1997.

98. Sekido Y: Molecular pathogenesis of malignant mesothelioma. Carcinogenesis 34: 1413-1419, 2013.
99. Kitasato Y, Hoshino T, Okamoto M, Kato S, Koda Y, Nagata N, Kinoshita M, Koga H, Yoon DY, Asao H, et al: Enhanced expression of interleukin-18 and its receptor in idiopathic pulmonary fibrosis. Am J Respir Cell Mol Biol 31: 619-625, 2004.

100. Lindroos PM, Coin PG, Osornio-Vargas AR and Bonner JC: Interleukin 1 beta (IL-1 beta) and the IL-1 beta-alpha 2-macroglobulin complex upregulate the platelet-derived growth factor alpha-receptor on rat pulmonary fibroblasts. Am J Respir Cell Mol Biol 13: 455-465, 1995.

101. Sabo-Attwood T, Ramos-Nino M, Bond J, Butnor KJ, Heintz N, Gruber AD, Steele C, Taatjes DJ, Vacek P and Mossman BT: Gene expression profiles reveal increased mClca3 (Gob5) expression and mucin production in a murine model of asbestosinduced fibrogenesis. Am J Pathol 167: 1243-1256, 2005.

102. Musumeci G, Loreto C, Giunta S, Rapisarda V, Szychlinska MA, Imbesi R, Castorina A, Annese T, Castorina S, Castrogiovanni P, et al: Angiogenesis correlates with macrophage and mast cell infiltration in lung tissue of animals exposed to fluoro-edenite fibers. Exp Cell Res 346: 91-98, 2016.

103. Cardile V, Lombardo L, Belluso E, Panico A, Renis M, Gianfagna A and Balazy M: Fluoro-edenite fibers induce expression of Hsp70 and inflammatory response. Int J Environ Res Public Health 4: 195-202, 2007. 